\title{
Systematic studies in the eucalypts - 2 * A revision of the gimlets and related species: Eucalyptus extracodical series Salubres and Annulatae (Myrtaceae)
}

\author{
L.A.S. Johnson \& K.D. Hill
}

\begin{abstract}
Johnson, L.A.S. E Hill, K.D. (National Herbarium of New South Wales, Royal Botanic Gardens, Sydney, NSW, Australia 2000) 1990. Systematic studies in the eucalypts - 2. A revision of the gimlets and related species: Eucalyptus extracodical series Salubres and Annulatae (Myrtaceae). Telopea 4(2): 201222. A taxonomic revision of the gimlets (series Salubres) and related gimlet-like species (series Annulatae) is presented. Twelve species are described, six of them new (E.jimberlanica, E. tortilis, E. terebra, E. Creta, E. extensa, E. protensa). A new name at new rank is provided for one species (E. ravida), and one new subspecies is described (E. effusa subsp. exsul). A classification is presented, with keys to subgroups and species.
\end{abstract}

\section{Introduction}

The vernacular name of 'gimlet' or 'gimlet gum' is applied to members of series Salubres (Eucalyptus L'Hérit., subgenus Symphyomyrtus section Bisectaria as defined by Pryor and Johnson 1971), which consists of two subseries, the gimlets proper (subseries Salubrosae, 8 species) and the closely related subseries Effusosae (1 species). Of rather similar appearance are the members of the series Annulatae ( 3 species), which share with the Salubres seed and bark characters that are probably synapomorphies. All species are confined to the south-west of Western Australia.

Names of sections, series and subseries used by us are intentionally published in a system (PJ) devised by Pryor \& Johnson (1971) and external to the International Code of Botanical Nomenclature. This avoids the confusion created by formal recognition of 'series' and 'subseries' that were used by Maiden (1903-1933) in a loose and informal sense, and classifying according to particular organ sets rather than as taxa. Moreover, as explained previously by Pryor \& Johnson (1971), it allows for clear application of names and categories. Since it has a perfectly clear formalism of its own, the term 'extracodical', rather than 'informal', is appropriate.

As in lists recently privately distributed to some eucalypt workers, subseries names here differ from those used by Pryor \& Johnson in ending with '-osae'. This is because '-inae' previously used is a subtribal ending (International Code of Botanical Nomenclature, 1988, Art. 19.2).

First to be named of the species treated here was E. annulata, described by Bentham (1867), who placed it in series Normales subseries Cornutae, with several other species. This was followed by E. salubris F. Muell. in 1876, E. campaspe S. Moore in 1899 and E. diptera C. Andrews in 1904.

* Number 1 in this series was published as L.A.S. Johnson \& K.D. Hill (1990) New taxa and combinations in Eucalyptus and Angophora (Myrtaceae). Telopea 4(1): 37-108. 
Maiden (1903-1933) recognised these four species, placing them in section Macrantherae subsection Longiores series Non-Corymbosae, with three in subseries 'Miscellaneous' and one (E. annulata) in subseries Cornutae (1925). He had sufficient detail on only one to include it in his seed classification (E. salubris, series Lepidotae-Fimbriatae, subgroup Af). He had also earlier (1919) recognised a variety (E. salubris var. glauca Maiden).

Blakely (1934) recognised the same four species, but placed them in four widely separated groups (E. annulata in section Macrantherae series Cornutae, E. campaspe in the same section, series Obliquae, E. diptera in the same section, series Dumosae subseries Dipterae, and E. salubris with its variety glauca in section Platyantherae series Contortae).

Pryor \& Johnson (1971) recognised these four species plus one unpublished, grouping all except E. annulata in their series Salubres. E. annulata was placed with a number of other species in their series Occidentales.

Chippendale (1988) followed Pryor \& Johnson, but used different series names, placing the first group in series Contortae (after Blakely) and E. annulata in series Micromembranae (after Maiden 1925). He recognised the same five species as Pryor \& Johnson, the fifth species having by then been published, viz. E. effusa Brooker.

Brooker and Kleinig (1990) recognised six species in series Salubres, two of them undescribed (species $\mathrm{G}$ and $\mathrm{H}$, described below as E. terebra and E. creta respectively). They recognised the distinctive nature of $E$. annulata, leaving it as an unplaced anomalous species.

We now consider these taxa and their hitherto undescribed relatives to constitute a probable clade within the large section Bisectaria of the subgenus Symphyomyrtus, this clade consisting of two distinctive subclades each of which can be circumscribed and reasonably treated as a series.

The names applied to series and subseries by earlier authors are cited above merely to indicate the way in which those authors grouped the species concerned. Nothing is implied about their standing, since we are using only the PJ extracodical system between genus and species. The series mentioned below are constituted as in the modified PJ system circulated by us as indicated above.

\section{Section Bisectaria}

Bisectaria is the largest section in subgenus Symphyomyrtus, comprising about 270 taxa (species and subspecies). The vast majority are restricted to the Mediterranean climatic region of south-western Western Australia, which is clearly the centre of origin and diversification for the group (although probably not possessing a 'Mediterranean' climate earlier in the history of the group). The deduced relationships of the taxa at the various levels lead strongly to the conclusion that the arid zone and eastern regions have been separately colonised on several occasions by members of different series, and several radiation and isolation events can be postulated (Hill 1989).

The section is characterised as follows: Cotyledons deeply bisected, varied in size and shape. Pith glands present or absent. Bark glands absent. Adult leaves amphistomatic (hypostomatic in E. dundasii). Phyllotaxis disjunct, opposite or (exceptionally and secondarily) spiral. Calyx calyptriform, free from corolla, shedding early in bud development (persistent to anthesis in subseries Caesiosae). Anthers versatile or adnate, highly varied in shape.

Prominent reticulation (i.e. veins at all grades raised above surrounding leaf surface) in early seedling leaves is probably a plesiomorphic character in Bisectaria. This fea- 
ture occurs in a number of series, in generally unspecialised taxa within the series. Examples are Loxophlebae, Prominentes, Sociales, Macrocarpae, and Orbifoliae. Reduncae and Desmondenses show prominence in only the main laterals, while Salubres and Annulatae show complete reduction in this feature.

Phylogenetic relationships of the series within Bisectaria remain to be clarified, although subgroups are generally clearly defined. One such distinct group is the pair Salubres plus Annulatae, treated here.

The series pair is characterised as follows: pith glands present; stomata small, green; cuticle smooth, glossy; anthers elongate, dorsifixed, versatile. Seeds irregular, ragged, deeply pitted; hilum ventral.

While most of these characters are probably plesiomorphic, the seeds are distinctive, and their characters are considered apomorphic conditions uniting the two series as sister groups. The distinctive smooth, glossy or subglossy brown or greenish new bark (aging to bronze or coppery) is also common throughout the two series, and most probably a synapomorphy (on the basis of outgroup comparison).

We are acquainted with all the taxa in the field.

\section{Key to the series, subseries and species}

1 Filaments erect in mature bud; stemonophore broad, overlying ovary top; disc narrow; oil glands in adult leaves spherical Series Annulatae

2 Peduncle narrow 12. E. protensa

2* Peduncle broadly flattened

3 Buds less than $18 \mathrm{~mm}$ long, fruit sessile

10. E. annulata

$3^{*}$ Buds more than $17 \mathrm{~mm}$ long, fruit pedicellate

11. E. extensa

$1^{*}$ Filaments inflexed in mature bud; stemonophore narrow; disc broad; oil glands in adult leaves irregularly angular

4 Mallees, bark persistent on trunk

Series Salubres

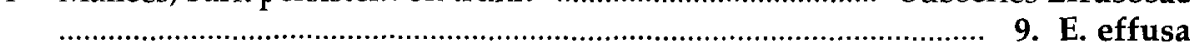

$4^{*}$ Trees, bark smooth to base

Subseries Salubrosae

5 Plants glaucous

6 Buds 5-8 $\mathrm{mm}$ diam., fruit $8-10 \mathrm{~mm}$ diam.

3. E. campaspe

$6^{*}$ Buds 4-5 mm diam., fruit 4-7 $\mathrm{mm}$ diam.

2. E. ravida

$5^{*}$ Plants not glaucous

7 Inflorescences 7-flowered

8 Buds sessile

$8^{*}$ Buds pedicellate

6. E. terebra

9 Buds 4-5 mm diam., fruit 4-7 mm diam.

9* Buds 5-7 mm diam., fruit 6-8 $\mathrm{mm}$ diam.

10 Calyptra acute

$10^{*}$ Calyptra hemispherical

$7^{*}$ Inflorescences 3-flowered

11 Buds 7-9 mm diam., fruit 9-14 mm diam.

$11^{*}$ Buds 9-12 mm diam., fruit 15-21 mm diam.

1. E. salubris

5. E. tortilis

4. E. jimberlanica

7. E. diptera

8. E. creta

\section{Series Salubres}

Pith glands present. Stomata small, green. Cuticle smooth, glossy. Oil glands in adult leaves irregularly angular. Filaments inflexed in mature buds; anthers elongate, dorsifixed, versatile. Disc broad; stemonophore narrow. Seeds irregular, ragged, deeply pitted; hilum ventral. 
In the series Salubres, the stemonophore is relatively narrow, the disc is broad and flat, the oil-glands of the adult (not juvenile) leaves have irregular laterally projecting angles, and are less densely packed than those of Annulatae, and the primary and secondary lateral veins of the leaves are more distinct.

The subseries Effusosae differs from the subseries Salubrosae in the mallee habit and partly persistent bark. The smooth bark is comparable to the smooth bark of the other gimlets.

\section{Subseries Salubrosae}

Trees. Bark smooth to base.

The eight species of this group are the 'gimlets' proper, so named because of the characteristic irregular often spiralled fluting of the trunk caused by non-uniform development of the wood. All species typically form small dense pure stands on strongly calcareous soils, often over greenstones (low-grade metamorphosed basic or ultrabasic igneous rocks). These stands characteristically include a low shrubby understorey of calcicole species such as Cratystylis conocephala, Atriplex and some Melaleuca species. Gimlet stands tend to occur on low but not swampy sites in the south of the range of the group, and more on low rises further to the north. This difference sometimes involves different gimlet species, although widespread taxa such as $E$. salubris and $E$. ravida follow the same pattern within their ranges.

Intergrading populations and some occasional hybrid individuals occur in places where the species meet, and are listed later under the various species involved (specimens of intergrading populations and hybrids are cited on p. 78 and distributions are given in Figure 13). There are however also many sites where gimlet taxa are sympatric and show no breakdown. This occurs over a wide area with E. salubris and $E$. ravida, with the two forming a fine mosaic rather than occurring in mixed stands. A similar pattern occurs with E. ravida and E. terebra, and E. terebra and E. creta occur in mixed stands with no apparent breakdown in the east of the range of the latter. No hybrids are recorded with taxa from other series or subseries apart from the one Annulatae-Salubres hybrid known.

\section{Eucalyptus salubris F. Muell., Fragm. 10: 54 (1876).}

Type citation: 'Inter Victoria-Spring et Ularing; Young.'

TYPE: WeSTERN Australia: between Victoria Spring and Ularing, J. Young, 9 Oct 1875 (holo MEL; iso K).

Tree to $20 \mathrm{~m}$ high, rarely $25 \mathrm{~m}$, branches erect and arising near base. Bark smooth throughout, glossy dark green-brown or bronze to brilliant copper. Adult leaves disjunct, similifacial, narrow-lanceolate to lanceolate, acute or acuminate, glossy green, $4.5-10.5 \mathrm{~cm}$ long, $0.7-1.8 \mathrm{~cm}$ wide; petioles $8-15 \mathrm{~mm}$ long; lateral veins moderately spaced, regular, at $30^{\circ}-40^{\circ}$ to midrib; intramarginal vein continuous, \pm distinct, to 1 $\mathrm{mm}$ from margin. Inflorescences simple, axillary; umbellasters 7 -flowered; peduncles thick, flattened, 4-14 mm long, to $4 \mathrm{~mm}$ wide apically; pedicels angular, 1-5 $\mathrm{mm}$ long. Mature buds ovoid, 7-12 $\mathrm{mm}$ long, 4-5 mm diam.; calyptra rounded or convexconical, obtuse, about as long as or slightly longer than hypanthium. Fruits obconical to cup-shaped, often 2-winged, 3-4-locular, 3-7 mm long, 4-7 mm diam.; disc slightly raised or flat, \pm incurved ultimately, $0.5-1.5 \mathrm{~mm}$ wide; valves broadly triangular, obtuse or acute, basally \pm enclosed, apically exserted, raised at $45^{\circ}-90^{\circ}$.

This species is distinguished by the non-glaucous branchlets, the 7-flowered umbellasters, and the small, pedicellate fruit. 
A widespread and common species in the northern and eastern wheat belt and eastwards, from between Morawa and Kondinin in the west to between Lake Minigwal and the Fraser Range in the east (Avon, Roe and Coolgardie Districts of Beard, 1980) (Figure 1).

While this species occurs in the characteristic small pure stands of most gimlet species as mentioned earlier, extensive open woodlands with admixed E. oleosa also occur in the region west and north-west of Norseman.

Intergrading populations are known with E. ravida, E. tortilis and E. diptera.

Selected SPECimens (from 47 examined): WeStern Australia (W to E): 5.2 miles [83.2 km] SSE of Maya, Chippendale 58, 21 Oct 1966 (NSW); 64 km SW of Paynes Find, Brooker 8717, 18 Oct 1984 (NSW); $13 \mathrm{~km}$ NW of Yoting, Crisp 5509, 27 Jan 1979 (NSW); $20.5 \mathrm{~km} \mathrm{~N}$ of Tammin on Wyalkatchem road, Johnson 9205 \& B. Briggs, 02 Nov 1988 (NSW, CANB, PERTH); Kununoppin, Stoward 205, Nov 1917 (NSW); Kondinin, Stoward 56, Jan 1917 (NSW); $22 \mathrm{~km}$ E of Merriden, Beadle 93, 25 May 1972 (NSW); Carrabin, Coveny 8348, 12 Sep 1976 (NSW); 0.6 miles [1 km] E of Bodallin, Chippendale 94, 6 Mar 1967 (NSW); 17 miles [27 km] from the Humps towards King Rocks, Wrigley, 10 Nov 1968 (NSW); 1 mile [1.6 km] W of Bullfinch, Phillips, 18 Sep 1962 (NSW); $19.6 \mathrm{~km} \mathrm{~N}$ of Diemals on Youanmi road, Hill 2611 \& Johnson, 25 Nov 1986 (NSW, PERTH); 2.9 $\mathrm{km}$ E of rabbit-proof fence on Varley - Southern Cross road, Hill 3049, 1 Sep 1988 (NSW); $22 \mathrm{~km}$ SSW of Coolgardie to Gnarlbine Rock, Crisp 5615, 31 Jan 1979 (NSW); 9 miles [16.4 km] N of Bullabulling, Fitzgerald, Nov 1903 (NSW); $76.8 \mathrm{~km} \mathrm{~W}$ of Coolgardie-Norseman road on Hyden track, Hill 614, Johnson \& Blaxell, 7 Nov 1983 (NSW); Mount Jessop, $9.6 \mathrm{~km} \mathrm{~W}$ of Kookynie, Hill 527,528 , Johnson $\mathcal{E}$ Blaxell, 4 Nov 1983 (NSW); 8 miles [12.5 km] N of Kalgoorlie, Speck 900, 5 July 1958 (NSW); $32 \mathrm{~km}$ N of Kambalda, Brooker 6402, 21 Aug 1979 (NSW); $21.1 \mathrm{~km} \mathrm{~S}$ of Widgiemooltha, Brooker 6408, 21 Aug 1979 (NSW); $15.3 \mathrm{~km} \mathrm{~N}$ of Norseman, Hill 586, Johnson $\mathcal{E}$ Blaxell, 6 Nov 1983 (NSW); $92 \mathrm{~km}$ E of Norseman on highway, Hill 2213 \& Johnson, 4 Nov 1986 (NSW, CBG, CANB, MEL, PERTH); S side Lake Minigwal, Brooker 8597, 16 May 1984 (NSW); $0.3 \mathrm{~km} \mathrm{~N}$ of roundabout $51.1 \mathrm{~km} \mathrm{~N}$ of Mulga Rock on Lake Minigwal track, Hill 2673 \& Johnson, 29 Nov 1986 (NSW, PERTH).
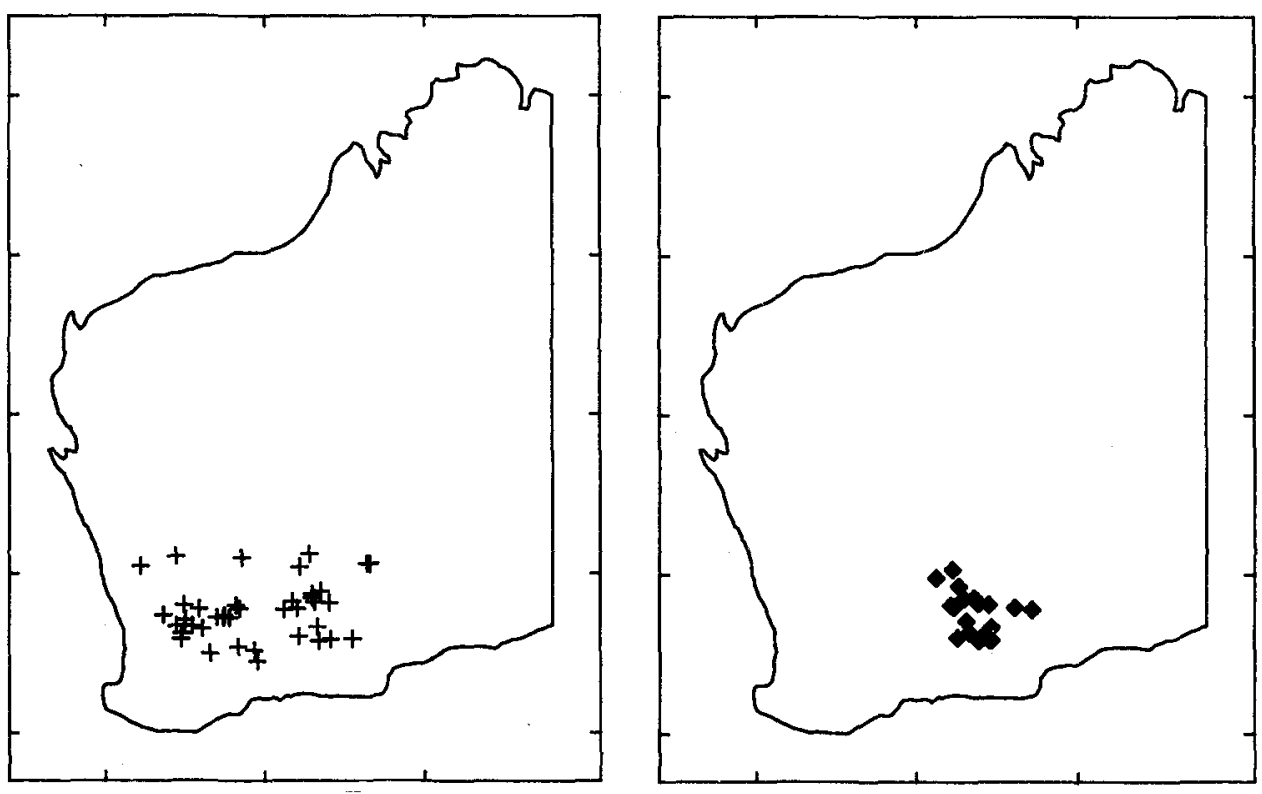

Figure 1. Distribution of E. salubris.

Figure 2. Distribution of E. ravida. 
2. Eucalyptus ravida L. Johnson $\mathcal{E} K$. Hill, nom. et stat. nov.

REPLACED NAME: E. salubris F. Muell. var. glauca Maiden, Crit. Revis. Eucalyptus 4: 158 (1919).

TYPE CITATION: 'Trees 70 miles north of Kurrawang (J.H.M.) are wholly glaucous and with sessile inflorescence.'

Type: Western Australia: 70 miles [112 km] N of Kurrawang, J.H. Maiden, Sep 1909 (holo NSW; iso CANB).

Tree to $20 \mathrm{~m}$ high, branches erect and arising near base. Bark smooth throughout, glossy dark green-brown or bronze to coppery; young branches strongly white-glaucous before bark first sheds. Adult leaves disjunct, similifacial, narrow-lanceolate to lanceolate, acute or acuminate, strongly glaucous when young, soon weathering to glossy green, 4.5-10.5 cm long, $0.7-1.8 \mathrm{~cm}$ wide; petioles 8-15 mm long; lateral veins moderately spaced, regular, at $30^{\circ}-40^{\circ}$ to midrib; intramarginal vein continuous, \pm distinct, to $1 \mathrm{~mm}$ from margin. Inflorescences simple, axillary; umbellasters 7 -flowered; peduncles thick, flattened, 4-14 $\mathrm{mm}$ long, to $7 \mathrm{~mm}$ wide apically; pedicels angular, 0-2 $\mathrm{mm}$ long. Mature buds ovoid, strongly glaucous, 7-12 $\mathrm{mm}$ long, 4-5 mm diam.; calyptra rounded or convex-conical, obtuse, about as long as hypanthium. Fruits glaucous, obconical to cup-shaped, often 2-winged, 3-4-locular, 3-7 mm long, 4-7 $\mathrm{mm}$ diam.; disc slightly raised or flat, \pm incurved ultimately, $0.5-1.5 \mathrm{~mm}$ wide; valves broadly triangular, obtuse or acute, basally \pm enclosed, apically exserted, raised at $45^{\circ}-90^{\circ}$.

NoTE: Included in E. salubris by Pryor \& Johnson (1971).

Distinguished within the subseries by the strongly glaucous branchlets, the 7-flowered umbellasters, and the small, pedicellate buds and fruit.

A common species in the central Goldfields districts, from Callion south to Norseman and east to Zanthus (Coolgardie and Eucla Districts) (Figure 2).

Intergrading populations with $E$. salubris are known and hybrids with $E$. tortilis are recorded.

The epithet is from the Latin ravidus, greyish, from the appearance of the tree caused by the glaucous twigs and immature adult leaves.

Selected specimens (from 27 examined): Western Australia ( $\mathrm{N}$ to S): $2.9 \mathrm{~km}$ N of Callion on road, Hill 2660 \& Johnson, 28 Nov 1986 (NSW, PERTH); $49 \mathrm{~km}$ N of Kalgoorlie, Hill 548, Johnson $\mathcal{E}$ Blaxell, 4 Nov 1983 (NSW); 6.6 miles [10.6 km] SW of Kalgoorlie, Chippendale 113, 8 Mar 1967 (NSW). $30 \mathrm{~km}$ E of Kalgoorlie, Blaxell 1651, 20 June 1978 (NSW); 4.7 miles [7.5 km] W of Curtin, Chippendale 134, 10 Mar 1967 (NSW); $52 \mathrm{~km}$ E of Karonie, Hill 557, Johnson \& Blaxell, 5 Nov 1983 (NSW); 7 miles [11 km] E of Coolgardie, Johnson W 162, 17 Dec 1960 (NSW); $6.4 \mathrm{~km}$ S of turnoff near Zanthus on Balladonia track, Hill 2695 \& Johnson, 30 Nov 1986 (NSW, PERTH); 2.6 miles [4.2 km] NNW of Widgiemooltha, Chippendale 379, 23 Mar 1968 (NSW); 40 miles [64 km] NW of Fraser Range, Helms, 5 Nov 1891 (NSW); 16 miles [26 km] N of Norseman, Ralph, 25 Oct 1973 (NSW); $36.4 \mathrm{~km}$ W of Coolgardie road on Hyden track, Hill 608, Johnson \& Blaxell, 7 Nov 1983 (NSW); 4.2 miles [6.7 km] E of Norseman, Baker 58, 13 Nov 1970 (NSW); $60 \mathrm{~km}$ E of Norseman, Hill 693 \& Blaxell, 14 Nov 1983 (NSW); $128.7 \mathrm{~km} \mathrm{~W}$ of Balladonia roadhouse on hwy, Hill 2835, 24 Aug 1988 (NSW).

3. Eucalyptus campaspe S. Moore, J. Linn. Soc., Bot. 34: 193 (1899).

TYPe citation: 'Hab. Ad Gibraltar mens. Oct. florescit.'

TYPE: WESTERn Australia: Gibraltar, 16 miles [26 km] SW of Kalgoorlie, S. Moore 95, 1895 (holo BM, NSW; iso K, MEL). The fragment in NSW was sent to J.H. Maiden by 
Moore, and was recorded as being a piece of the Holotype (Crit. Revis. Eucalyptus 2: 216).

Tree to $12 \mathrm{~m}$ high, branches erect and arising near base. Bark smooth throughout, yellow-brown to dark green-brown, bronze or reddish copper. Adult leaves disjunct, similifacial, lanceolate, acute or acuminate, strongly glaucous, dull, sometimes weathering to sub-glossy green, 7-12 cm long, 1-2 cm wide; petioles $10-15 \mathrm{~mm}$ long; lateral veins moderately spaced, regular, at $30^{\circ}-40^{\circ}$ to midrib; intramarginal vein continuous, \pm distinct, to $1 \mathrm{~mm}$ from margin. Inflorescences simple, axillary; umbellasters 7-flowered; peduncles thick, flattened, $4-9 \mathrm{~mm}$ long, to $5 \mathrm{~mm}$ wide apically; pedicels angular, 1-4 mm long. Mature buds strongly glaucous, ovoid, 9-13 mm long, 5-8 mm diam.; calyptra hemispherical, about as long as hypanthium. Fruits strongly glaucous, hemispherical, often 2-winged, 3-4-locular, 6-9 mm long, 8-10 mm diam.; disc slightly raised or flat, \pm incurved ultimately, $1-3 \mathrm{~mm}$ wide; valves broadly triangular, obtuse or acute, basally \pm enclosed, apically exserted, raised at c. $45^{\circ}$.

All parts strongly glaucous. Leaves mostly dull. Umbellasters 7-flowered. Buds large, rounded. Fruit large, almost sessile.

Restricted to the vicinity of Coolgardie and Kalgoorlie (Coolgardie District) (Figure 3).

E campaspe tends to occur more exclusively on ultrabasic rock outcrops than the other gimlet species.

Selected Specimens (from 26 examined): Western Australia ( $\mathrm{N}$ to S): 19.3 miles [30.1 km] SW of Kalgoorlie, Chippendale 117, 8 Mar 1967 (NSW); 7.5 km from Coolgardie to Kalgoorlie, Hill 574, Johnson \& Blaxell, 6 Nov 1983 (NSW); $2 \mathrm{~km} \mathrm{~N}$ of Coolgardie, Blaxell 1659, 21 June 1978 (NSW); 1.2 miles [1.9 km] E of Coolgardie, Baker 123, 23 Nov $1970(\mathrm{NSW}) ; 7$ miles [11 km] E of Coolgardie, Johnson W 163, 17 Dec 1960 (NSW); 2.6 miles [4.2 km] SE of Coolgardie, Chippendale 138, 11 Mar 1967 (NSW); $8 \mathrm{~km} \mathrm{~S}$ of Coolgardie, Beadle 69, 28 May 1972 (NSW); Comet Hill, on roadside $11.0 \mathrm{~km}$ S of Coolgardie, Hill $2635 \mathcal{E}$ Johnson, 26 Nov 1986 (NSW, PERTH); $19 \mathrm{~km} \mathrm{SSW}$ of Coolgardie, Crisp 5616, 31 Jan 1979 (NSW); $31.5 \mathrm{~km} \mathrm{SE}$ of Coolgardie, Brooker 7047, 09 Nov 1981 (NSW).

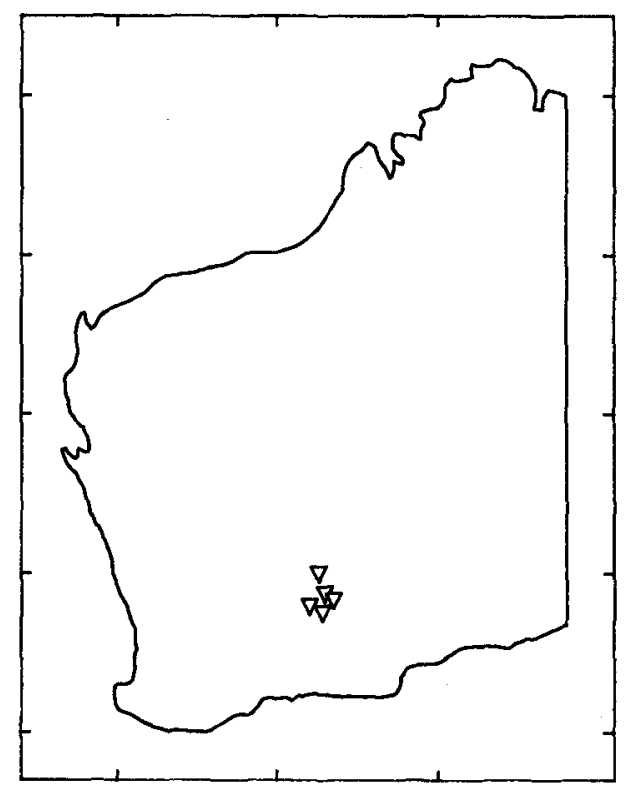

Figure 3. Distribution of E. campaspe. 


\section{Eucalyptus jimberlanica L. Johnson \& K. Hill, sp. nov.}

Inter species subsectionis distinguitur: haud glauca; umbellastrae 7-florae; alabastra magna, rotundata; fructus magni, subsessiles.

Type: Western Australia: Jimberlana Hill, NE of Norseman, K. Hill 599, L. Johnson $\mathcal{E}$ D. Blaxell, 6 Nov 1983 (holo NSW).

Tree or mallee to $10 \mathrm{~m}$ high, branches erect and arising near base. Bark smooth throughout, glossy dark green-brown or bronze to coppery. Adult leaves disjunct, similifacial, narrow-lanceolate to lanceolate, acute or acuminate, glossy green, 4.5-9.0 $\mathrm{cm}$ long, $0.5-1.8 \mathrm{~cm}$ wide; petioles to $1.3 \mathrm{~cm}$ long; lateral veins moderately spaced, regular, at $30^{\circ}-50^{\circ}$ to midrib; oil glands large, stellate, moderately to sparsely distributed; intramarginal vein continuous, \pm distinct, $0.3-1.0 \mathrm{~mm}$ from margin. Inflorescences simple, axillary; umbellasters 7-flowered; peduncles thick, flattened, 2-9 mm long, to $4 \mathrm{~mm}$ wide apically; pedicels angular, 1-2 mm long. Mature buds ovoid to globular, 7-10 mm long, 6-8 mm diam.; calyptra hemispherical, about as long as hypanthium or slightly longer. Fruits obconical to cup-shaped, often 2-winged, 4-locular, 7-9 mm long, 6-8 mm diam.; calyptra scar raised at $\pm 45^{\circ}, 0.5-1.0 \mathrm{~mm}$ wide; stemonophore raised, $0.2-0.5 \mathrm{~mm}$ wide; disc slightly raised or flat, \pm incurved ultimately, $0.5-1.0 \mathrm{~mm}$ wide; valves broadly triangular, obtuse or acute, basally \pm enclosed, apically exserted, raised at $30^{\circ}-70^{\circ}$. Figure 4 .

Distinguished within the subseries as follows: branchlets not glaucous, inflorescences 7-flowered, buds large, rounded, fruits large, almost sessile.

Known from a single small population near Norseman (Coolgardie District). No other gimlets are in the immediate vicinity (Figure 5).

The epithet refers to the only known locality.

SPECIMENS eXAMINED: Western Australia: W foot of Jimberlana Hill, NE of Norseman, Hill 2838, 24 Aug 1988 (NSW).
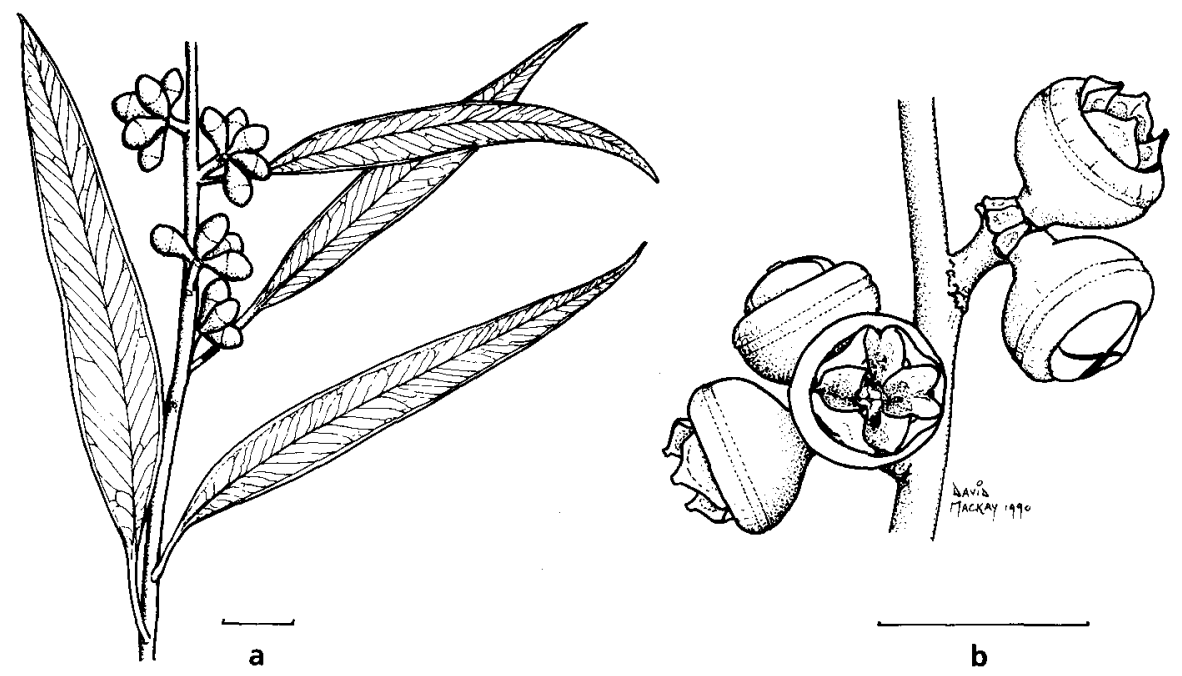

Figure 4. E. jimberlanica. a, adult leaves and buds. b, fruits (all from Hill 2838). Scale bar $=1 \mathrm{~cm}$. 
The following four species exhibit a geographic replacement pattern with overlap of $E$. terebra and E. creta in the southeast (Burgman 1985). Species of this group occur more on residual calcareous loams, whereas the previous species are found more on basic or ultrabasic outcrops.

\section{Eucalyptus tortilis L. Johnson $\mathcal{E} K$. Hill, sp. nov.}

Inter species subsectionis distinguitur: haud glauca; umbellastrae 7-florae; alabastra magna, breviter pedicellata; calyptra longa, acuta; fructus longiores quam latiores.

TYPE: Western Australia: $52.2 \mathrm{~km}$ E of Norseman on Eyre Highway, (32 ${ }^{\circ} 03^{\prime} \mathrm{S} 122^{\circ}$ 06'E), K. Hill 688 \& D. Blaxell, 14 Nov 1983 (holo NSW; iso CANB, K, PERTH).

Tree or mallee to $10 \mathrm{~m}$ high, branches erect and arising near base. Bark smooth throughout, glossy dark green-brown or bronze to coppery. Adult leaves disjunct, similifacial, narrow-lanceolate to lanceolate, acute or acuminate, glossy green, 4.5-9.0 $\mathrm{cm}$ long, $0.5-1.8 \mathrm{~cm}$ wide; petioles to $1.3 \mathrm{~cm}$ long. Lateral veins moderately spaced, regular, at $30^{\circ}-50^{\circ}$ to midrib; oil glands large, stellate, moderately to sparsely distributed; intramarginal vein continuous, \pm distinct, $0.3-1.0 \mathrm{~mm}$ from margin. Inflorescences simple, axillary; umbellasters 7-flowered. Peduncles thick, flattened, 2-9 mm long, to $4 \mathrm{~mm}$ wide apically. Pedicels angular, 1-2 mm long. Mature buds ovoid, 10-14 mm long, 5-7 mm diam.; calyptra convex, acute, 1.5-2 times as long as hypanthium. Fruits obconical to cup-shaped, often 2-winged, 4-locular, 7-9 mm long, 6-8 $\mathrm{mm}$ diam.; calyptra scar raised at $\pm 45^{\circ}, 0.5-1.0 \mathrm{~mm}$ wide; stemonophore raised, $0.2-0.5 \mathrm{~mm}$ wide; disc slightly raised or flat, + incurved ultimately, $0.5-1.0 \mathrm{~mm}$ wide; valves broadly triangular, obtuse or acute, basally \pm enclosed, apically exserted, raised at $30^{\circ}-70^{\circ}$. Figure 6.

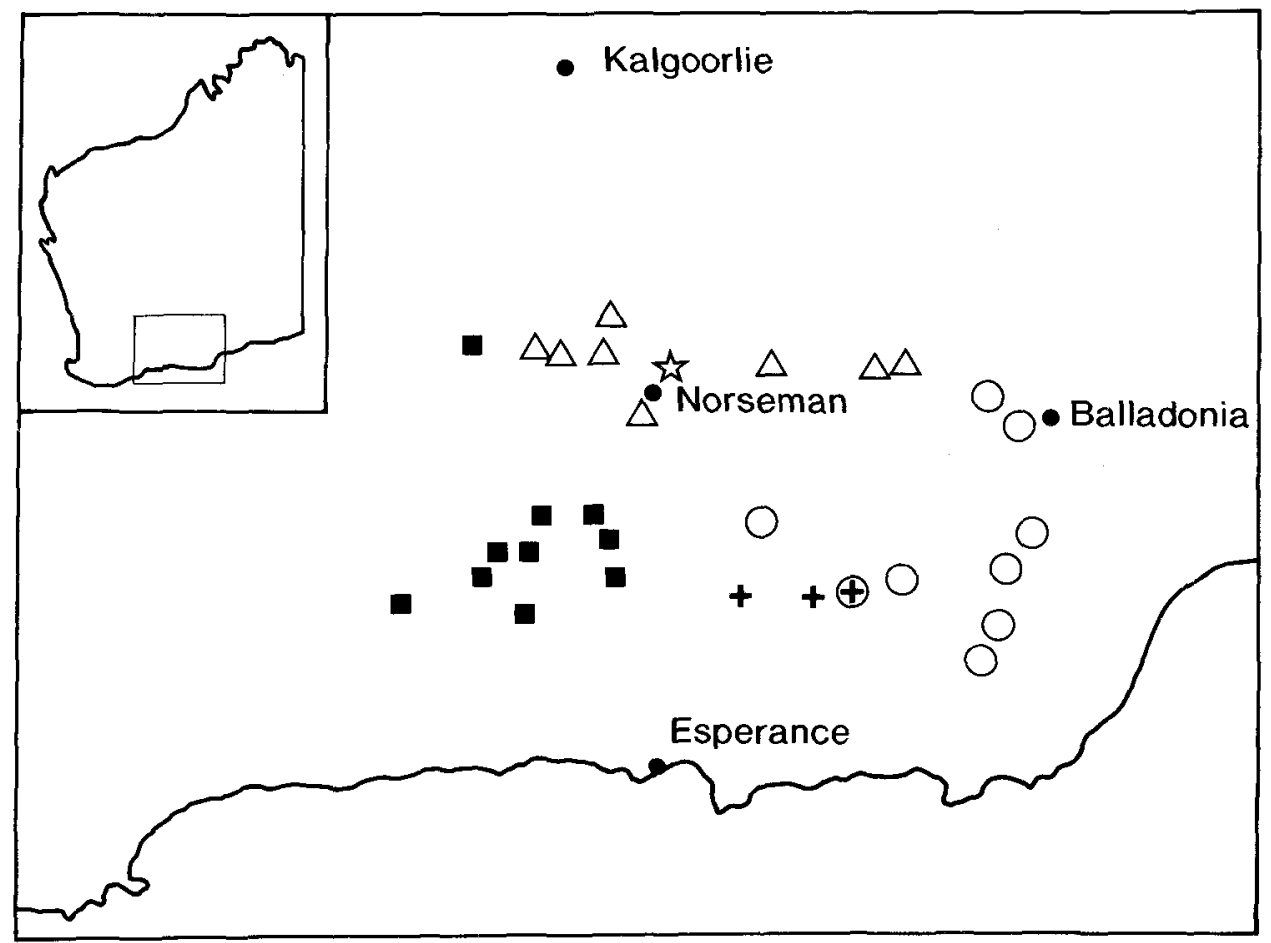

Figure 5. Distribution of E. jimberlanica ( $\lesssim$, E. tortilis $(\triangle)$, E. terebra $(O)$, E. diptera $(\boldsymbol{\square})$ and E. $\operatorname{creta}(+)$. 
Distinguished as follows: branchlets not glaucous; umbellasters 7-flowered; buds large, shortly pedicellate; calyptra long, acute; fruits longer than broad.

E. tortilis shows some approach to E. salubris, which is finer and more delicate in all parts.

Distributed from west of Norseman to the Fraser Range (Coolgardie District) (Figure 5).

Sporadic in distribution but locally abundant, usually in woodlands on calcareous loams, mostly on slightly elevated, level sites with a wide range of associated species.

Hybrids are recorded with E. terebra and E. salubris.

The epithet is from the Latin tortilis, twisted, referring to the 'gimlet' trunk.

Selected SPECIMENS (from 11 examined): WesteRn Australia (W to E): $14.1 \mathrm{~km} \mathrm{~W}$ of CoolgardieNorseman road on Hyden track, Hill 602, Johnson \& Blaxell, 7 Nov 1983 (NSW); $7.6 \mathrm{~km}$ W of Coolgardie-Norseman road on Hyden track, Brooker 8350, 7 Nov 1983 (CANB, NSW, PERTH); $120 \mathrm{~km} \mathrm{~S}$ of Coolgardie along hwy, Hill 583, L. Johnson \& Blaxell, 6 Nov 1983 (NSW); c. $20 \mathrm{~km}$ S of Norseman, Blaxell 1670, 21 June 1978 (NSW); $60 \mathrm{~km}$ E of Norseman, Hill 691 \& Blaxell, 14 Nov 1983 (NSW); $130 \mathrm{~km} \mathrm{~W}$ of Balladonia, Beadle 54, 28 Oct 1972 (NSW); $128.7 \mathrm{~km} \mathrm{~W}$ of Balladonia roadhouse on hwy, Hill 2836, 24 Aug 1988 (NSW); $69 \mathrm{~km} \mathrm{~W}$ of Balladonia roadhouse, Hill 228 \& Johnson, 19 Oct 1983 (NSW).
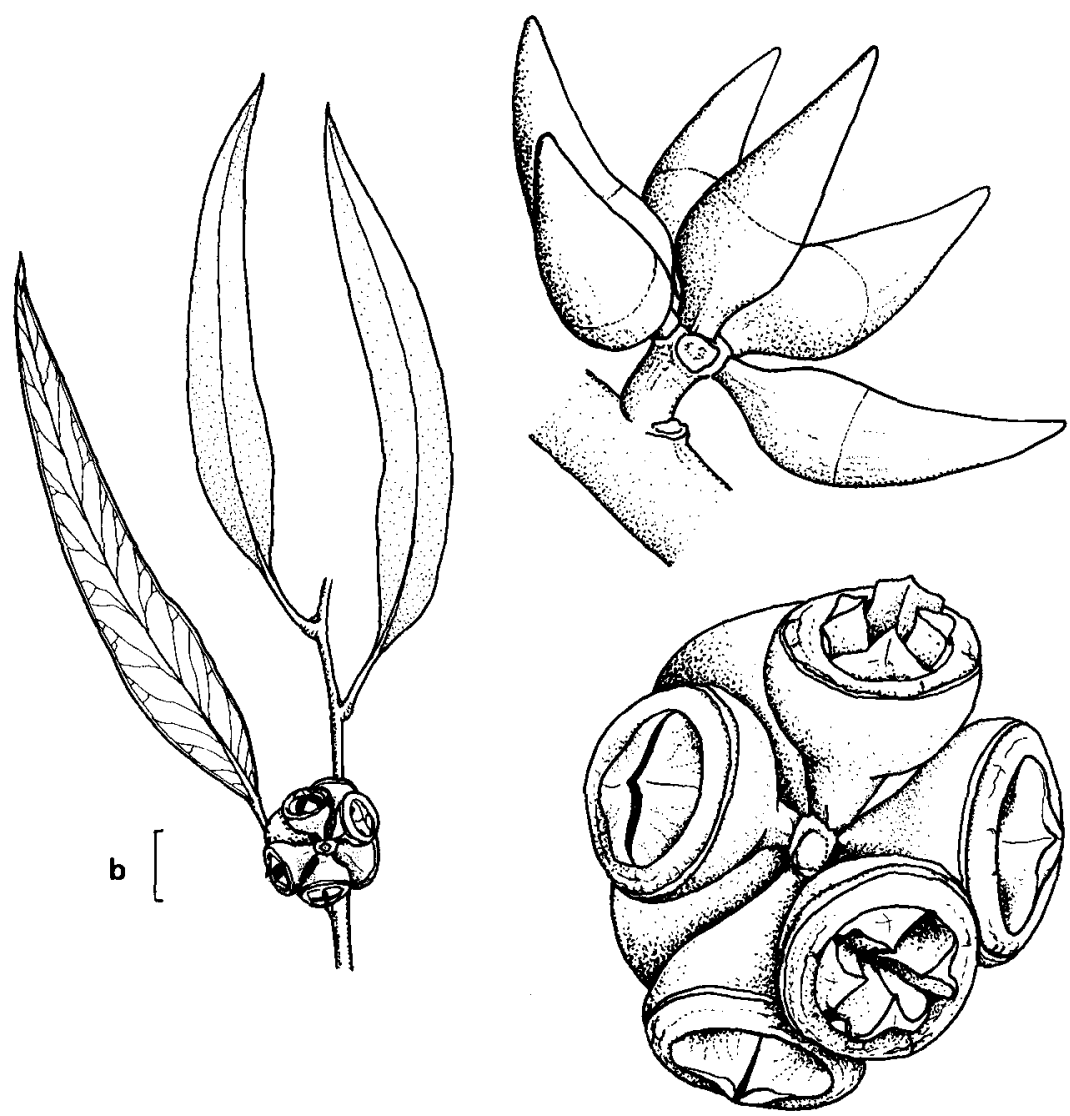

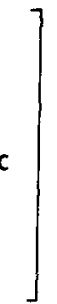

Figure 6. E. tortilis. a, buds. b, adult leaves and fruits. c, fruits (a from Hill $688 \&$ B Blaxell, b, c from Chippendale 50 ). Scale bar: $\mathrm{a}, \mathrm{b}, \mathrm{c}=1 \mathrm{~cm}$. 


\section{Eucalyptus terebra L. Johnson \& K. Hill, sp. nov.}

Inter species subsectionis distinguitur: haud glauca; umbellastrae 7-florae; fructus sessiles, latiores quam longiores.

TYPE: Western Australia: $16.7 \mathrm{~km} \mathrm{~W}$ of Balladonia Roadhouse along Highway 1 $\left(32^{\circ} 16^{\prime} \mathrm{S}, 123^{\circ} 28^{\prime} \mathrm{E}\right), K$. Hill $210 \mathcal{E}$ L. Johnson, 19 Oct 1983 (holo NSW; iso CANB, PERTH, MEL, K).

Tree or sometimes mallee, to $11 \mathrm{~m}$ high. Bark smooth, shining, dark bronze or greenish brown to coppery. Adult leaves lanceolate or narrow-lanceolate, disjunct, acuminate, similifacial, distinctly glossy, $4-8 \mathrm{~cm}$ long, $0.5-1.1 \mathrm{~cm}$ wide; petioles $0.6-$ $1.4 \mathrm{~cm}$ long; lateral veins irregular, widely spaced, at $30-45^{\circ}$ to midrib; intramarginal vein distinct, $0.5-1 \mathrm{~mm}$ from margin; oil glands widely scattered, large. Umbellasters simple, axillary, 7-flowered; peduncles terete, 1-2 mm long. Mature buds sessile, globular, sometimes apiculate, $9-10 \mathrm{~mm}$ long, $7-8 \mathrm{~mm}$ diam.; calyptra as long as hypanthium or slightly longer. Fruits broadly hemispherical to campanulate, 4-locular, 6-8 mm long, 8-10 mm diam.; calyptra scar 1.0-1.5 mm wide, vertically raised, almost continuous with hypanthium; disc $1-2 \mathrm{~mm}$ wide, flat; valves broadly triangular, exserted, incurved. Figure 7.

Distinguished by the non-glaucous branchlets; the 7-flowered umbellasters; and the sessile fruits, which are much broader than long.

Locally common between the Fraser Range and Balladonia, south almost to Mt Heywood (Coolgardie and Roe Districts) (Figure 5).

Usually in dense but scattered stands in low woodland on calcareous sandy loams, associated with E. oleosa, E. melanoxylon, E. flocktoniae, E. eremophila, and E. fraseri.

The epithet is from the Latin terebra, a gimlet, used as a noun and not an adjective. The stress is best placed on the second ' $\mathrm{e}$ ', pronounced long.

Selacted specimens (from 16 examined): Western Australia ( $\mathrm{N}$ to $\mathrm{S}$ ): $\mathrm{c} .15-20 \mathrm{~km} \mathrm{NW}$ of Balladonia, Brooker 6440, 22 Aug 1979 (NSW); $4.4 \mathrm{~km} \mathrm{~W}$ of Balladonia, Brooker 7480, 28 Apr 1982 (NSW); $63.1 \mathrm{~km} \mathrm{~S}$ of Balladonia roadhouse, Hill 236 \& Johnson, 20 Oct 1983 (NSW); Coragina Rock, Beard 5282, 27 Oct 1967 (NSW); $20 \mathrm{~km} \mathrm{E} \mathrm{of} \mathrm{'Beard} \mathrm{site',} \mathrm{Burgman,} 1983$ (NSW); $51.4 \mathrm{~km} \mathrm{NE}$ of Howick Road on survey track, Hill 297 \& Johnson, 21 Oct 1983 (NSW); 30 miles [48 km] NE of Mt Ney, Beard 6372, 17 Sep 1970 (NSW); $30.7 \mathrm{~km} \mathrm{~N}$ of Israelite Bay turnoff at Mt Ragged on track to Balladonia, Hill 3171, 9 Sep 1988 (NSW); 7 miles [11 km] N of Pine Hill, Brooker 4534, 10 Apr 1974 (NSW).

7. Eucalyptus diptera C. Andrews, J. Proc. Mueller Bot. Soc. Western Australia 1: 42 (1904).

TYPE CITATION: 'I found this species in flower north of Esperance, in October 1903.'

TyPe: Western Australia: N of Esperance, C. Andrews, Oct 1903 (holo PERTH; iso NSW).

Tree or sometimes mallee, to $10 \mathrm{~m}$ high. Bark smooth, shining, dark bronze or greenish brown to coppery. Adult leaves lanceolate or narrow-lanceolate, disjunct, acuminate, similifacial, distinctly glossy, $6-9 \mathrm{~cm}$ long, $0.8-1.5 \mathrm{~cm}$ wide; petioles $0.6-$ $1.4 \mathrm{~cm}$ long; lateral veins irregular, widely spaced, at $30-45^{\circ}$ to midrib; intramarginal vein distinct, $0.5-1 \mathrm{~mm}$ from margin; oil glands widely scattered, large, stellate. Umbellasters simple, axillary, 3-flowered; peduncles terete, 1-2 mm long. Mature buds sessile, globular to ovoid, apiculate, 2-winged, 9-13 $\mathrm{mm}$ long, 7-10 $\mathrm{mm}$ diam; calyptra as long as hypanthium or slightly longer. Fruits broadly hemispherical to campanulate, 2-winged, 4-locular, 7-10 $\mathrm{mm}$ long, 9-15 mm diam.; calyptra scar 1-2 mm wide, vertically raised, almost continuous with hypanthium; disc 1-2 $\mathrm{mm}$ wide, flat; valves broadly triangular, exserted, incurved. 


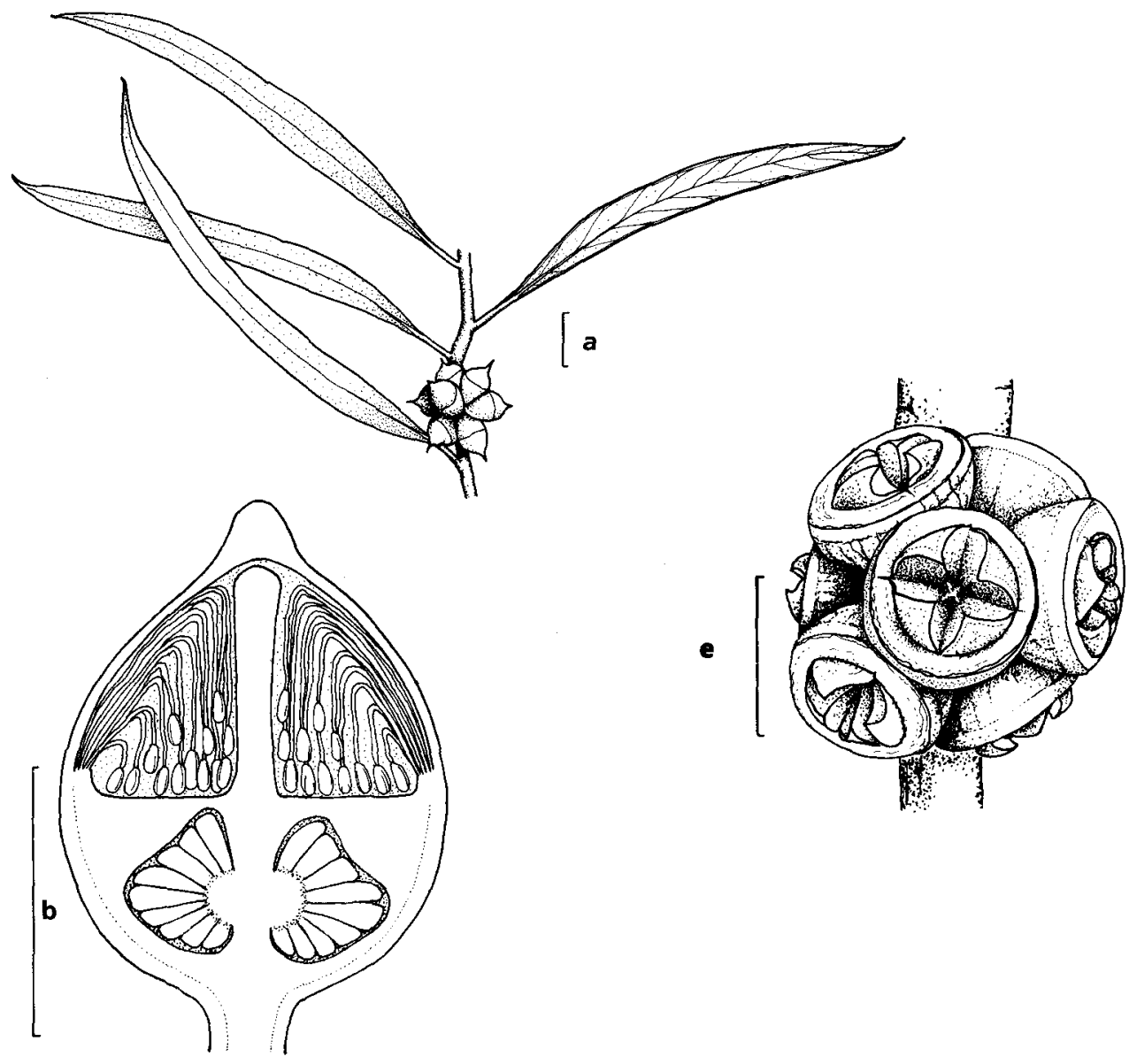

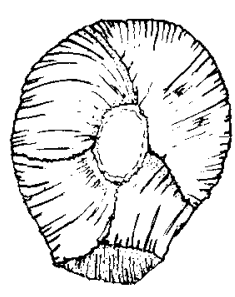

f

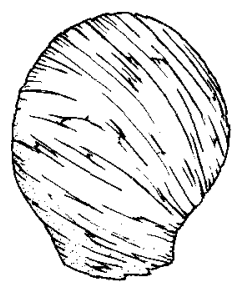

g

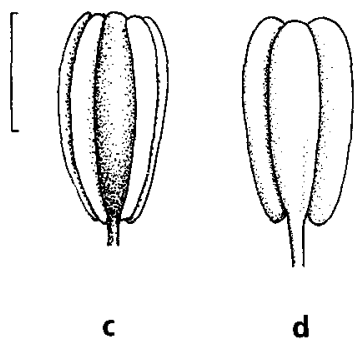

Figure 7. E. terebra. a, adult leaves and buds. $\mathbf{b}$, median section of bud. $\mathbf{c}, \mathbf{d}$, anther; $\mathbf{e}$, fruits. $\mathbf{f}, \mathbf{g}$, seed (all from Hill 290 \& Johnson). Scale bar: $\mathrm{a}, \mathrm{e}=1 \mathrm{~cm} ; \mathrm{b}=5 \mathrm{~mm} ; \mathrm{f}, \mathrm{g}=1 \mathrm{~mm} ; \mathrm{c}, \mathrm{d}=0.5 \mathrm{~mm}$. 
Distinguished by the non-glaucous branchlets; the 3-flowered umbellasters; and the sessile fruits which are much broader than long.

Locally common over a restricted area between Kumarl and south of Salmon Gums, extending west into uninhabited country some distance northeast of Ravensthorpe (Roe District) (Figure 5).

Hybrids are recorded with E. salubris and E. terebra.

Selected SPEcimens (from 18 examined): Western Australia ( $\mathrm{N}$ to S): $56.6 \mathrm{~km} \mathrm{~W}$ of CoolgardieNorseman road on Hyden track, Hill 612, Johnson \& Blaxell, 7 Nov 1983 (NSW); 10 miles [16 km] W of Esperance-Norseman road to Lake King, Cranfield 749, 23 Sep 1978 (NSW); 0.5 miles [0.8 $\mathrm{km}$ ] N of Kumarl, Baker 66, 13 Nov 1970 (NSW); 2 miles [3.2 km] S of Kumarl, Johnson W187, 18 Dec 1960 (NSW); $70 \mathrm{~km} \mathrm{~S}$ of Norseman, Blaxell 1676, 21 June 1978 (NSW); $1.4 \mathrm{~km} \mathrm{~N}$ of Peak Charles, Brooker 7501, 02 May 1982 (NSW); 9.8 miles [15.7 km] NW of Salmon Gums, Chippendale 392, 24 Mar 1968 (NSW); 2 miles [3.2 km] N of Salmon Gums, Brooker 2497, 15 Feb 1970 (NSW); Salmon Gums, Gardner 2226, 24 May 1924 (NSW); $20 \mathrm{~km} \mathrm{~W}$ of Peak Charles Road from Cups Road, Burgman, 1983 (NSW); $3.1 \mathrm{~km} \mathrm{~N}$ of southern boundary of Peak Charles National Park, Brooker 9534, 08 Nov 1986 (NSW); $80 \mathrm{~km} \mathrm{NE}$ of Ravensthorpe, Crisp 6036, 21 Sep 1979 (NSW); $5 \mathrm{~km} \mathrm{~W}$ of Lort River, Brooker 7129, 12 Nov 1981 (NSW).

\section{Eucalyptus creta L. Johnson $\mathcal{E}$ K. Hill, sp. nov.}

Inter species subsectionis distinguitur: haud glauca; umbellastrae triflorae; omnes partes grossae; fructus distincte latiores quam longiores.

TYPe: Western Australia: 51.4 km NE of Howick Road on Mt Ney track, K. Hill $296 \mathcal{E}$ L.A.S. Johnson, 21 Oct 1983 (holo NSW; iso CANB, PERTH).

Tree to $10 \mathrm{~m}$ high. Bark smooth, shining, yellow-brown, dark bronze or greenish brown to coppery. Adult leaves lanceolate or narrow-lanceolate, disjunct, acuminate, similifacial, distinctly glossy, $6-10 \mathrm{~cm}$ long, $1-1.8 \mathrm{~cm}$ wide; petioles $0.6-1.2 \mathrm{~cm}$ long; lateral veins irregular, widely spaced, at $30-45^{\circ}$ to midrib; intramarginal vein distinct, $0.5-$ $1.5 \mathrm{~mm}$ from margin; oil glands widely scattered, large, stellate. Umbellasters simple, axillary, 3-flowered; peduncles terete, 1-3 mm long. Mature buds sessile, globular to ovoid, apiculate; calyptra as long as hypanthium or slightly longer, acuminate. Fruits broadly hemispherical to campanulate, 2-winged, 4-5-locular, 9-12 mm long, 15-21 mm diam.; calyptra scar 1.5-2.5 mm wide, vertically raised, almost continuous with hypanthium; disc $1.5-3 \mathrm{~mm}$ wide, flat; valves broadly triangular, exserted, incurved. Figure 8.

Distinguished by the non-glaucous branchlets; the 3-flowered umbellasters; and the fruits much broader than long. All parts are generally larger and coarser than in other gimlets.

Locally common in remote country between $122^{\circ} \mathrm{E}$ and $123^{\circ} \mathrm{E}$, and $32^{\circ} 45^{\prime} \mathrm{S}$ and $33^{\circ}$ 15’S (Roe District) (Figure 5).

Associated with E. terebra in the eastern parts of the range (of E. creta), but apparently not interbreeding.

From the Latin cretus, grown bigger, referring to the buds, flowers and fruit. The epithet has no connection with that of E. cretata Lang \& Brooker (1990), a member of a different section (Dumaria). The epithets are not orthographical variants or homonyms. The epithet 'creta' was used on herbarium collections and in lists distributed by us well before 'cretata' was made known.

Selected specimens (from 6 examined): Western Australia (N to S): $15 \mathrm{~km}$ W of 'Beard site', Burgman, 1983 (NSW); 30 miles [48 km] NE of Mt Ney, Beard 6371, 16 Sep 1970 (NSW); $28.0 \mathrm{~km}$ $\mathrm{N}$ of Mt Ridley turnoff on Dempster road, Hill 2254, Johnson, Brooker $\mathcal{E}$ Blaxell, 5 Nov 1986 (NSW, 


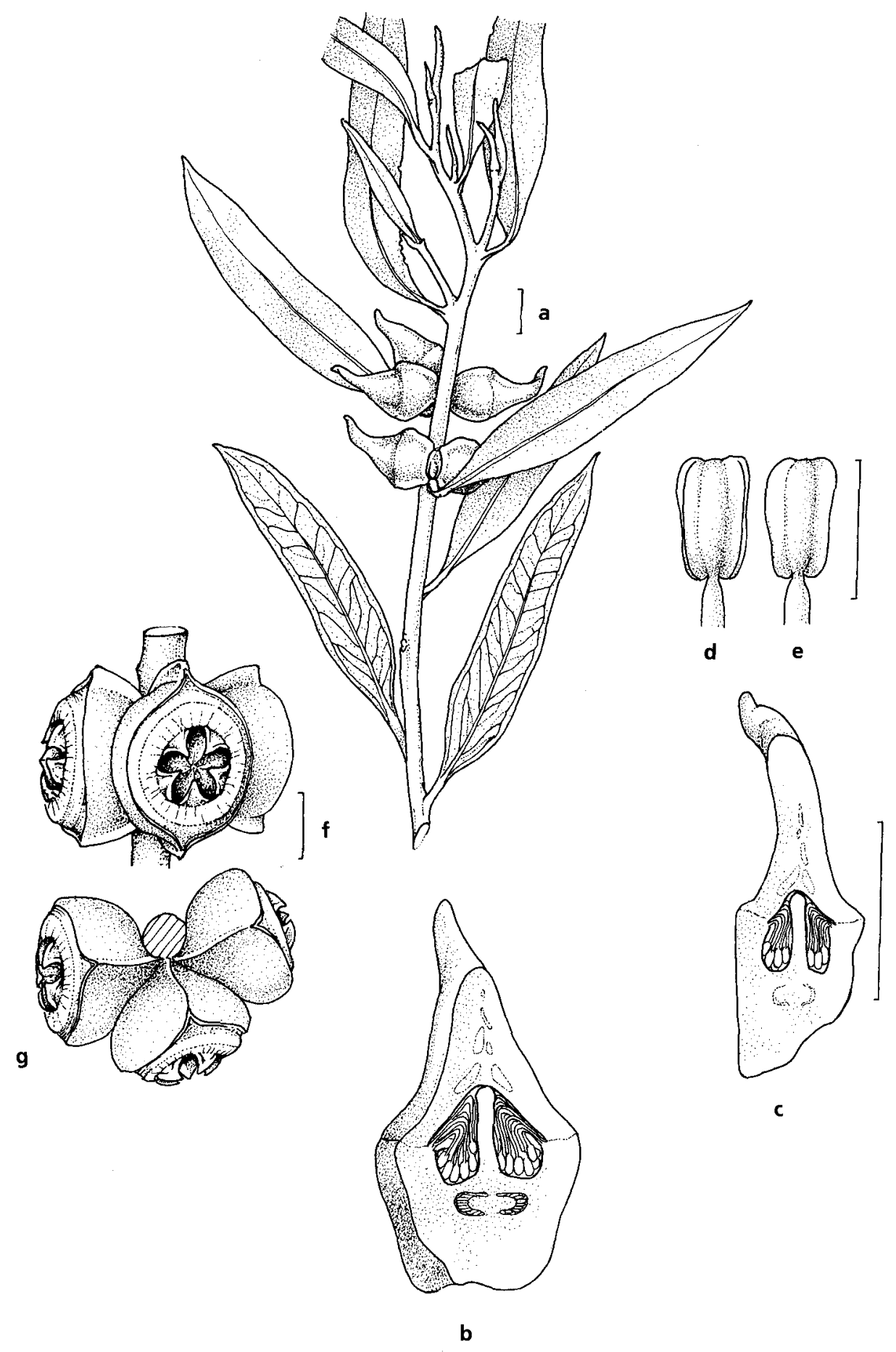

Figure 8. E. creta. $\mathbf{a}$, adult leaves and buds. $\mathbf{b}, \mathbf{c}$, median sections of buds. $\mathbf{d}$, $\mathbf{e}$, anther $\mathbf{f}, \mathbf{g}$, fruits (all from Beard 6371). Scale bars: $a, b, c, f, g=1 \mathrm{~cm}$;,$e=5 \mathrm{~mm}$. 
CBG, CANB, MEL, PERTH); $27.3 \mathrm{~km}$ NE on Dempster Rd from Mt Ridley turnoff, Brooker 8922, 9 Apr 1985 (NSW).

\section{Subseries Effusosae}

Mallees. Bark rough on trunk.

The subseries Effusosae differs from the subseries Salubrosae in having some persistent bark, but the smooth areas are comparable to the smooth bark of the other gimlets. The ecological preferences are also different, this group occurring on shallow or skeletal soils on rocky or lateritic slopes.

A subseries of one species.

9. Eucalyptus effusa Brooker, Nuytsia 2(2): 108, Figure 5 (1976).

TYPE CitATion: 'Type: $112 \mathrm{~km}$ E of Norseman by road towards Balladonia, Western Australia (32 $02^{\prime}$ S, $122^{\circ} 57^{\prime}$ E) 12 Mar. 1967, G.M. Chippendale 157 (Holo: FRI; Iso: NSW, MEL, PERTH).'

TYPE: the holotype is now held in CANB.

Tree or mallee to $4 \mathrm{~m}$ high. Bark persistent, ribbony or subfibrous to $2.5 \mathrm{~m}$, smooth, glossy green-brown above. Seedling leaves oblanceolate, obtuse, petiolate, opposite. Juvenile leaves broad-lanceolate to ovate, acute, petiolate, opposite to 8-10th node; then disjunct, lanceolate. Adult leaves disjunct, lanceolate, acute or acuminate, glossy, $5-10 \mathrm{~cm}$ long, $0.6-1.5 \mathrm{~cm}$ wide; petioles terete, $0.5-1.0 \mathrm{~cm}$ long; lateral veins at $30-45^{\circ}$ to midrib, moderately to widely spaced, \pm irregular, incipiently degenerate; reticulum obscure; intramarginal vein usually obscure or at edge of leaf. Umbellasters axillary, 7-flowered; peduncles \pm flattened, 3-13 mm long; pedicels terete, 1-3 mm long. Mature buds ovoid, 6-7 mm long, 3-4 mm diam.; calyptra conical or hemispherical to oblong, rounded or obtuse, 1-1.5 times longer than hypanthium. Stamens all fertile; filaments inflexed in bud; anthers elongate-ovoid, basifixed, versatile; cells \pm divergent, dehiscing by long parallel slits. Fruits cup-shaped, 3-locular, 4-7 mm long, 5-6 mm diam.; calyptra scar \pm continuous with hypanthium, c. $0.5 \mathrm{~mm}$ wide; disc flat, c. $1 \mathrm{~mm}$ wide; valves broadly triangular, flat or slightly exserted. Seeds flattened, discoid, finely and deeply pitted, toothed around the edge, dull orange-brown, c. $1.5 \mathrm{~mm}$ diam.; hilum ventral; chaff similar, smaller, angular.

Two widely disjunct subspecies are recognised.

\section{Key to the subspecies}

1 Branchlets not glaucous; calyptra conical 9A. subsp. effusa

1* Branchlets distinctly glaucescent; calyptra rounded 9B. subsp. exsul

\section{A. Eucalyptus effusa Brooker subsp. effusa}

Bark persistent to $2.5 \mathrm{~m}$. Branchlets not glaucous. Adult leaves 5-10 cm long, 0.7-1.5 $\mathrm{cm}$ wide; petioles $7-10 \mathrm{~mm}$ long. Peduncles 3-10 $\mathrm{mm}$ long, pedicels $1-3 \mathrm{~mm}$ long. Calyptra conical.

Locally frequent on shallow soils over greenstones (amphibolites) on the Fraser Range between Norseman and Balladonia (Coolgardie district) (Figure 9).

Selected specimens (from 14 examined): Western Australia (W to E): $115 \mathrm{~km}$ E of Norseman, Pullen 9595, 23 Nov 1974 (NSW); 70 miles [112 km] E of Norseman, Chippendale 157, 12 Mar 1967 (NSW); $66 \mathrm{~km} \mathrm{~W}$ of Balladonia, Strid 21927, 04 Jan 1983 (NSW); $150 \mathrm{~km}$ E of Norseman, Brooker 6425, 21 Aug 1979 (NSW); Southern Hill Station, Fraser Range, Beard 6300, 12 Sep 1970 (NSW); 
$32 \mathrm{~km} \mathrm{~W}$ of Balladonia, Brooker 7486, 28 Apr 1982 (NSW); $30 \mathrm{~km} \mathrm{~W}$ of Balladonia, Hill $224 \mathcal{E}$ Johnson, 19 Oct 1983 (NSW).

9B. Eucalyptus effusa Brooker subsp. exsul L. Johnson $\mathcal{E} K$. Hill, subsp. nov.

Ab subspecie typica ramulis glaucescentibus calyptra rotundata et pedunculis $7 \mathrm{~mm}$ excedentibus differt.

Type: Western Australia: $141.9 \mathrm{~km}$ NE of Paynes Find towards Sandstone $\left(28^{\circ} 37^{\prime} \mathrm{S}\right.$, $118^{\circ} 47^{\prime} \mathrm{E}$ ), L.D. Pryor $133 \mathcal{E}$ J.D. Briggs, 21 Oct 1978 (holo NSW; iso CANB).

Bark persistent to $1.5 \mathrm{~m}$. Branchlets glaucescent. Adult leaves $5-9 \mathrm{~cm}$ long, $0.5-1.2 \mathrm{~cm}$ wide; petioles 5-11 mm long. Peduncles $8-13 \mathrm{~mm}$ long, pedicels $2-3 \mathrm{~mm}$ long. Calyptra hemispherical to oblong.

Known only from a small area near Youanmi (Austin District), where the apparently small populations occur on shallow red loam over lateritic soil residuals (Figure 9).

The epithet is from the Latin exsul, an exile, from its occurrence in far isolation from the other subspecies.

Selected specimens (from 7 examined): Western Australia ( $\mathrm{N}$ to S): $75 \mathrm{~km}$ SW of Sandstone, Brooker 9258, 18 Apr 1986 (NSW); $83.1 \mathrm{~km}$ from Sandstone towards Paynes Find, Brooker 8711, 17 Oct 1984 (NSW, CANB); 3.7 km SW of Youanmi crossroad on Paynes Find road, Hill 2595 \& Johnson, 24 Nov 1986 (NSW, PERTH).

\section{Series Annulatae}

Pith glands present. Stomata small, green. Cuticle glossy. Oil glands in adult leaves spherical, densely packed. Filaments erect. Anthers elongate, dorsifixed, versatile. Disc very narrow. Stemonophore broad, raised and overlying ovary. Valves raised, acuminate. Seeds irregular, ragged and deeply pitted; hilum ventral.

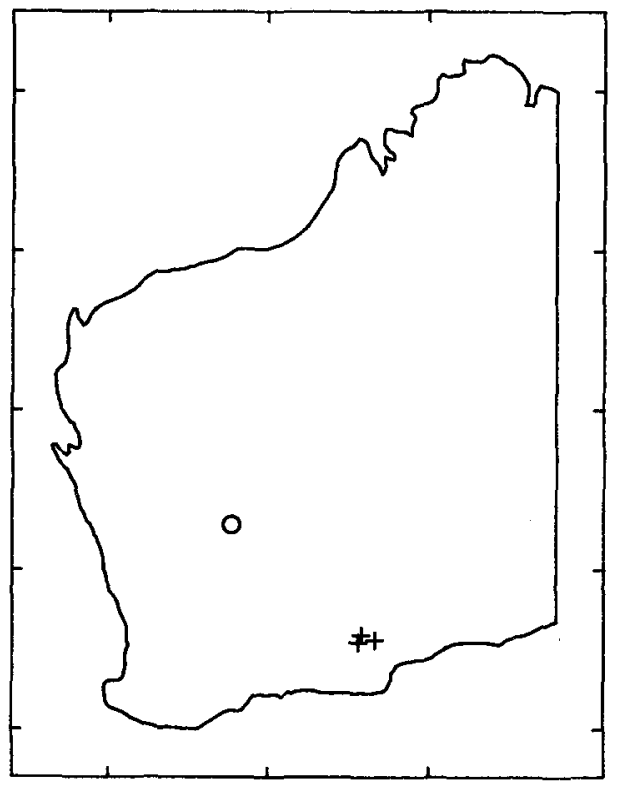

Figure 9. Distribution of E. effusa subsp. effusa (+) and E. effusa subsp. exsul (O). 
Members of series Annulatae differ from those of series Salubres in having erect filaments in bud, a strongly produced stemonophore overlying most of the ovary top, a very narrow or almost obsolete disc, and raised, acuminate valves in the fruits.

The three species recognised in this subseries exhibit a geographic replacement pattern (Figure 10).

10. Eucalyptus annulata Benth., Fl. Austral. 3: 234 (1867).

Type citation: 'W. Australia, Salt River, Maxwell.'

TYPE: holo K; iso MEL.

Tree to $8 \mathrm{~m}$ high, branches erect and arising near base. Bark smooth throughout, glossy or semiglossy dark green-brown or bronze to yellow-brown. Adult leaves disjunct, similifacial, narrow-lanceolate to lanceolate, acute or acuminate, glossy green, 6-10 $\mathrm{cm}$ long, $1.0-1.5 \mathrm{~cm}$ wide; petioles $10-20 \mathrm{~mm}$ long; lateral veins moderately spaced, regular, at $30^{\circ}-40^{\circ}$ to midrib; intramarginal vein continuous, \pm distinct, to $1 \mathrm{~mm}$ from margin. Inflorescences simple, axillary; umbellasters 7-flowered; peduncles thick, flattened, 5-10 mm long, to $9 \mathrm{~mm}$ wide apically. Mature buds sessile, cylindrical, basally angular, 13-18 mm long, 4-6 mm diam.; calyptra cylindrical to elongate conical, acute, 3-4 times as long as hypanthium. Fruits obconical to cup-shaped, often basally angular, 3-4-locular, 6-7 mm long, 8-11 mm diam.; disc slightly raised or flat, \pm incurved ultimately, $0.5-1.5 \mathrm{~mm}$ wide; valves broadly triangular, obtuse or acute, basally \pm enclosed, apically vertically exserted.

Distinguished by the flat peduncle; the sessile buds and fruits; and the calyptra rounded at the tip.

Locally frequent in almost pure stands on heavier soils, from between Dumbleyung and north of the Stirling Range in the west, east to north of Mt Ney (Roe and Eyre Districts) (Figure 10).

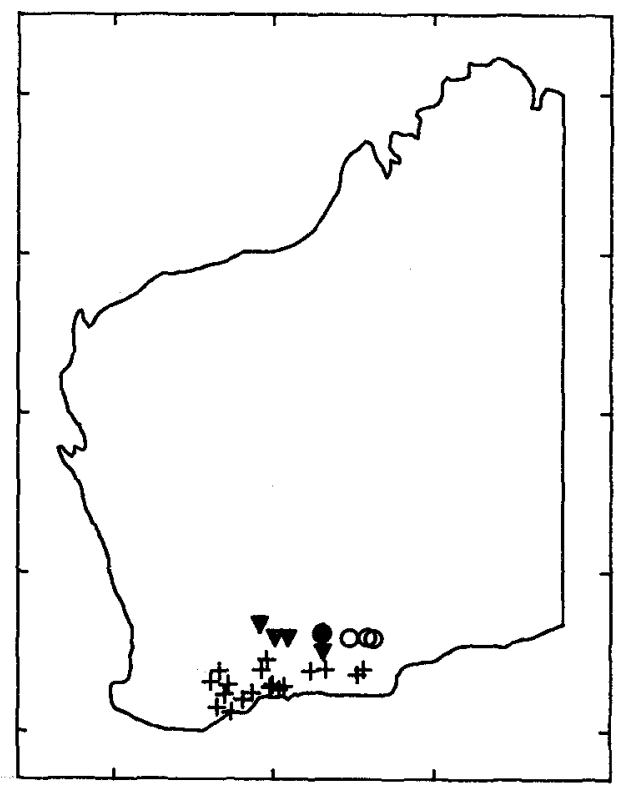

Figure 10. Distribution of E. annulata $(+)$, E. extensa $(\boldsymbol{\nabla})$, E. protensa $(O)$ and E. extensa E. protensa intergrade $(\bullet)$. 
Selected specimens (from 29 examined): Western Australia (W to E): Gnowangerup, Grasby, 12 Nov 1916 (NSW); 6 miles [9.6 km] from Lake Grace towards Kukerin, Wrigley, 9 Nov 1968 (NSW); 7.5 miles [12.1 km] NNW of Ongerup, Tindale 3896 \& Newbey, 31 Aug 1973 (NSW); $2.8 \mathrm{~km}$ from Pingrup-Newdegate road on Range Road, Brooker 9125, 27 Nov 1985 (NSW); Cheyne Bay, Brooker 8740, 29 Nov 1984 (NSW); W of Pallinup River, Brooker 8871, 2 Mar 1985 (NSW); 5.7 km S of Monkey Rock Road on Carlawillup Road, Hill 3119, 6 Sep 1988 (NSW); $17 \mathrm{~km}$ SE of Jerramungup, Foreman 1349, 30 Nov 1985 (NSW); corner Devils Creek Road \& Carlawillup South Road, Brooker 9908, 9 Mar 1988 (NSW, CANB); 1 mile [1.6 km] to Newdegate from Lake King, Wrigley, 6 Nov 1968 (NSW); 7.4 km E of rabbit-proof fence on Varley - Southern Cross road, Hill 3050, 1 Sep 1988 (NSW, CANB, PERTH); 8 miles [12.8 km] NW of Ravensthorpe, Chippendale 219, 17 Mar 1967 (NSW); 16 km S of Ravensthorpe, Crisp 5000, 10 Jan 1979 (NSW); $16 \mathrm{~km}$ N of Rollands Road on Fields Road, Hill 2314, Johnson \& Blaxell, 7 Nov 1986 (NSW, CBG, CANB, MEL, PERTH); Dowak, N of Salmon Gums, Johnson W190, 18 Dec 1960 (NSW); $15.8 \mathrm{~km}$ NE of Logans Road on Mt Ney Road, Hill 2256 \& Johnson, 5 Nov 1986 (NSW, CBG, CANB, MEL, PERTH); 24.7 km NE of Howick Road, along survey track, Hill $295 \&$ Johnson, 21 Oct 1983 (NSW);

\section{Eucalyptus extensa L. Johnson $\mathcal{E} K$. Hill, sp. nov.}

Inter species subsectionis distinguitur: pedunculi applanati; alabastra fructusque pedicellati; calyptra apice rotundata.

Type: Western Australia: $14.7 \mathrm{~km}$ N of Hyden-Norseman track along Mt Day track, turnoff $123.0 \mathrm{~km} \mathrm{~W}$ of Norseman-Coolgardie road $\left(32^{\circ} 07^{\prime} \mathrm{S}, 120^{\circ} 29^{\prime} \mathrm{E}\right), \mathrm{K}$. Hill 626, L. Johnson, D. Blaxell, I. Brooker, S. Hopper, 7 Nov 1983 (holo NSW; iso CANB, K, PERTH).

Tree or mallee to $8 \mathrm{~m}$ high. Bark smooth throughout, semiglossy, grey, grey-green, brown or yellow. Adult leaves disjunct, similifacial, narrow- to broad-lanceolate,

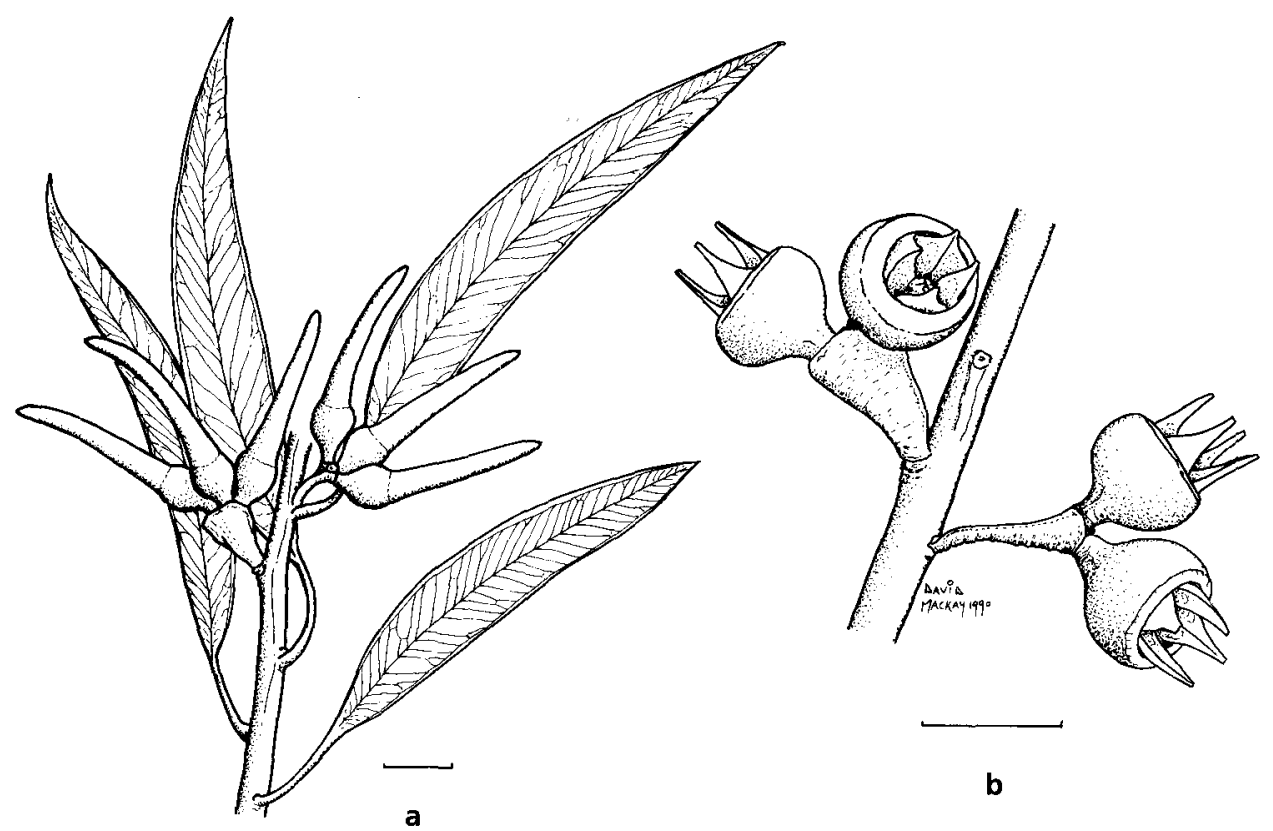

Figure 11. E. extensa. a, adult leaves and buds. b, fruits (all from Blaxell 1677). Scale bars $=1 \mathrm{~cm}$. 
obtuse, apiculate, $5-9 \mathrm{~cm}$ long, $0.7-1.7 \mathrm{~cm}$ wide; petioles to $1.3 \mathrm{~cm}$ long; lateral veins moderately spaced, regular, at $30^{\circ}-45^{\circ}$ to midrib; reticulum obscure; oil glands large, densely packed; intramarginal vein continuous, distinct, $0.5-1.0 \mathrm{~mm}$ from margin. Inflorescences simple, axillary; umbellasters 7-flowered; peduncles flattened, 8-12 mm long, 4-8 $\mathrm{mm}$ wide apically; pedicels terete or angular, 1-3 $\mathrm{mm}$ long. Mature buds elongate-cylindrical, 17-25 mm long, 5-7 mm diam.; calyptra cylindrical, obtuse, 4-6 times longer than hypanthium. Fruits cup-shaped to globular-truncate, 3-4-locular, 6-8 mm long, 7-10 mm diam.; calyptra scar raised at c. $45^{\circ}, 0.5-1.0 \mathrm{~mm}$ wide; stemonophore slightly raised, ultimately incurved, $0.5-1.5 \mathrm{~mm}$ wide; valves narrowly triangular, elongate, acute, basally enclosed, apically strongly vertically exserted and ultimately out-turned. Figure 11.

Distinguished by the flat peduncles; the pedicellate buds and fruits; and the calyptra rounded at the tip.

Locally frequent from Mt Day to south of Norseman (Coolgardie District) (Figure 10). Limited intergrades are recorded with $E$. protensa.

The epithet is from the Latin extensus, extended, referring to the long calyptra and the developed pedicels.

Selected specimens (from 7 examined): Western Australia (N to S): $91.6 \mathrm{~km} \mathrm{~N}$ of CoolgardieHyden road on Varley - Southern Cross road, Hill 2905, 26 Aug 1988 (NSW, CANB, PERTH); 23 miles [37 km] SW of Norseman, Chippendale 169, 13 Mar 1967 (NSW); 27 miles [43 km] SW of Norseman, Chippendale 387, 24 Mar 1967 (NSW); c. $70 \mathrm{~km}$ S of Norseman, Blaxell 1677, 21 June 1978 (NSW).

\section{Eucalyptus protensa L. Johnson $\mathcal{E} K$. Hill, sp. nov.}

Inter species subsectionis distinguitur: pedunculi teretes; alabastra fructusque pedicellati; calyptra apice acuta; fructus majusculi, globulares.

TYPe: Western Australia: $60 \mathrm{~km}$ E of Norseman along Eyre Highway (32 $\left.04^{\prime} \mathrm{S}, 1^{\circ} 2^{\circ} 22^{\prime} \mathrm{E}\right)$, K. Hill 690 \& D. Blaxell, 14 Nov 1983 (holo NSW; iso CANB, K, PERTH).

Tree branched at or near base, or mallee, to $10 \mathrm{~m}$ high. Bark smooth, semiglossy, greygreen or olive to yellow-brown, shedding in ribbons. Adult leaves glossy, lanceolate, to $15 \mathrm{~cm}$ long, $1.5 \mathrm{~cm}$ wide, petioles $1.0-1.8 \mathrm{~cm}$ long; lateral veins widely spaced, at $15^{\circ}-30^{\circ}$ to midrib; reticulum degenerate; oil glands large, densely packed; intramarginal vein distinct, continuous, $0.5-1.0 \mathrm{~mm}$ from margin. Umbellasters axillary, 7-flowered; peduncles \pm terete, vaguely 2-angled, to $15 \mathrm{~mm}$ long; pedicels terete or faintly angled, to $7 \mathrm{~mm}$ long. Mature buds elongate-cylindrical, apically tapered, 30-45 $\mathrm{mm}$ long, 7-9 mm diam.; calyptra cylindrical, tapered, acute, much narrower than hypanthium, c. 6-8 times longer than hypanthium. Fruit globular or hemispherical, 3- or 4-locular, 7-10 mm long, 8-13 mm diam.; disc and calyptra scar flat, c. $0.5 \mathrm{~mm}$ wide; stemonophore flat to slightly raised, ultimately incurved, $1.0-1.5 \mathrm{~mm}$ wide; valves narrowly triangular, basally enclosed, apically strongly vertically exserted, long acuminate, bases enclosed. Seeds dull, brown, fringed, flattened. Figure 12.

Distinguished by the terete peduncles; the pedicellate buds and fruits; the very long acute calyptra; and the large, globular fruits.

Locally frequent in the country to the east and west of the Fraser Range, between Norseman and Balladonia (Coolgardie District). Usually on calcareous soils on greenston (Figure 10).

Intergrades are recorded with $E$. extensa in the limited area of contact. 


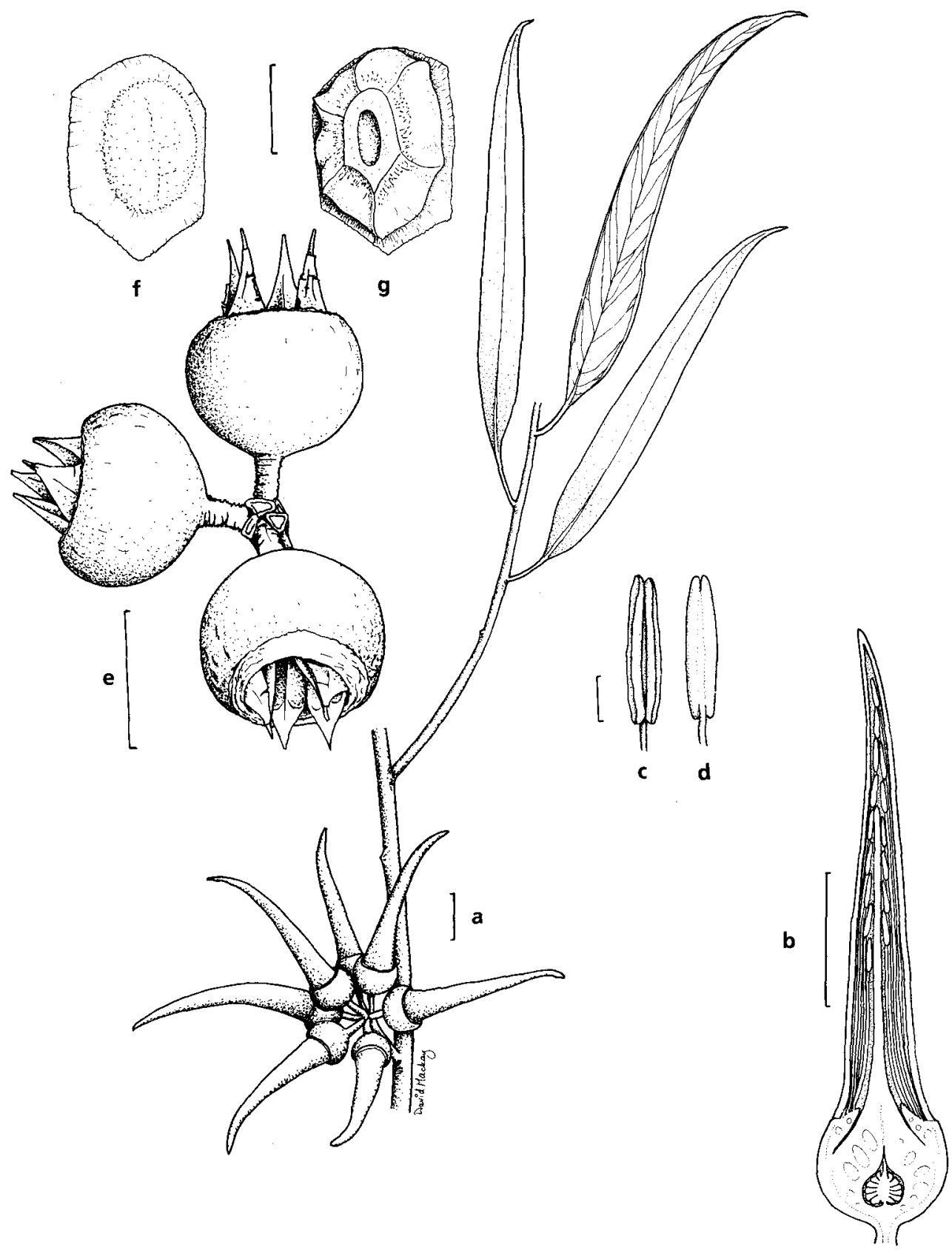

Figure 12. E. protensa. a, adult leaves with buds. b, median section of bud. $\mathbf{c}, \mathbf{d}$, anther. e, fruits. f, g, seed (all from Hill 690 \& Johnson). Scale bar: a, b, e =1 cm; c, d, f, g=1 mm. 
The epithet is from the Latin protensus, elongated, referring to the very long calyptra.

Selected specimens (from 8 examined): Western Australia (W to E): $125 \mathrm{~km}$ E of Norseman, Brooker 6453, 22 Aug 1979 (NSW); $74 \mathrm{~km} \mathrm{~W}$ of Balladonia roadhouse, Hill 233 E Johnson, 19 Oct 1983 (NSW); $71 \mathrm{~km}$ from Balladonia motel, Crisp 5645, 02 Feb 1979 (NSW); $55.3 \mathrm{~km} \mathrm{~W}$ of Balladonia roadhouse on hwy, Hill 2823, 24 Aug 1988 (NSW); $54.5 \mathrm{~km} \mathrm{~W}$ of Balladonia roadhouse on highway, Hill $2206 \mathcal{E}$ Johnson, 4 Nov 1986 (NSW, CBG, CANB, MEL, PERTH).

\section{Intergrading populations and hybrids}

Specimens cited as from intergrading populations are from sizeable populations with intermediate characters between those of the parent species. Distributions of these populations are given in Figure 13. Those cited as hybrids are from single occurrences of an individual in an area where the two parent species grow together and where there is no apparent evidence of interbreeding beyond the $F_{1}$ generation.

E. ravida - E. salubris (9 specimens examined): $37 \mathrm{~km} \mathrm{~W}$ of Coolgardie, Brooker 6470, 23 Aug 1979 (NSW, CANB); Bullabulling, Stoward 89, Mar 1971 (NSW); 8 miles [12.5 km] E of Merredin, Johnson W124A, 16 Dec 1960 (NSW); 6.3 miles [10 km] E of Ghooli, Chippendale 268, 11 Aug 1967 (NSW, CANB).

E. salubris - E. tortilis ( 3 specimens examined): $17 \mathrm{~km} \mathrm{E}$ of grid in rabbit-proof fence $\mathrm{E}$ of Hyden, Brooker 8622, 9 Aug 1984 (NSW); $93.7 \mathrm{~km}$ W of Balladonia roadhouse on hwy, Hill 2826, 24 Aug 1988 (NSW); $51 \mathrm{~km} \mathrm{~N}$ of Ravensthorpe, Hill 316, 317, Johnson \& Blaxell, 22 Oct 1983 (NSW).

E. diptera - E. salubris (5 specimens examined): 24.6 miles [39.4 km] S of Norseman, Brooker 2492, 15 Feb 1970 (NSW); 3.8 km N of Hayes Road on North Road, Hill 3029, 1 Sep 1988 (NSW); 16.1 $\mathrm{km}$ from Highway on Peak Charles road, Hill 2322, Johnson \& Blaxell, 8 Nov 1986 (NSW, PERTH).

E. diptera - E. terebra (1 specimen examined): $52.8 \mathrm{~km} \mathrm{~W}$ of Coolgardie-Norseman road on Hyden track, Hill 2855, 25 Aug 1988 (NSW).

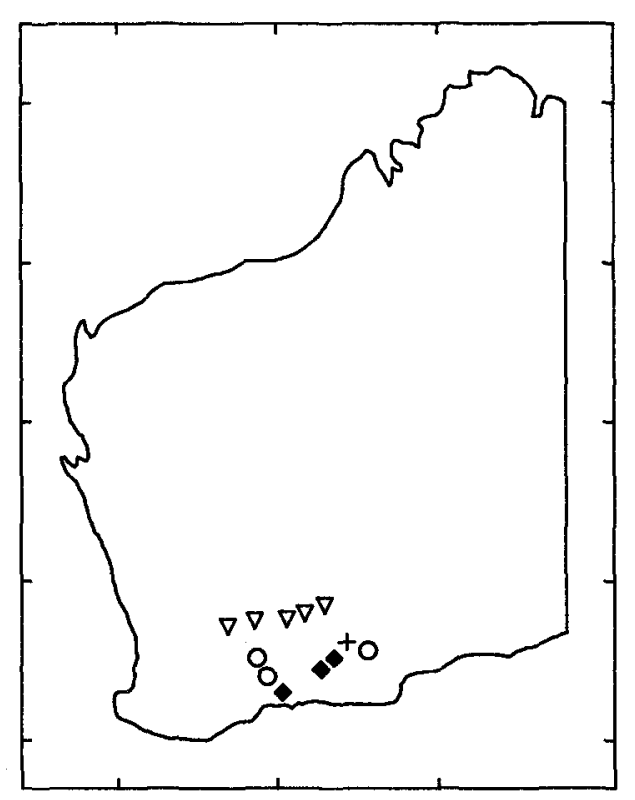

Figure 13. Distributions of the intergrades E. ravida - E. salubris $(\nabla)$, E. salubris - E. tortilis $(O)$, E. diptera $-E$. salubris $(\$)$ and E. diptera - E. terebra $(+)$. 
E. ravida $x$ E. tortilis (1 specimen examined): $47.5 \mathrm{~km}$ E of Norseman, Hill 2221 \& Johnson, 4 Nov 1986 (NSW, CANB, CBG, MEL, PERTH).

E. extensa - E. protensa (1 specimen examined): $30 \mathrm{~km} \mathrm{NW}$ of Norseman, Crisp 5940, Taylor $\mathcal{E}$ Jackson, 19 Sep 1979 (NSW).

E. annulata $\times$ E. creta (1 specimen examined): $42.8 \mathrm{~km} \mathrm{NE}$ of Logans road on Mt Ney road, Hill 2259 \& Johnson, 5 Nov 1986 (NSW).

This is the only interserial hybrid known for any of the species treated.

\section{Acknowledgements}

Our colleague in the overall project, Don Blaxell, has contributed helpful discussions on many points and has been involved the recognition of several of the taxa. Thanks are due to Leonie Stanberg, who has provided essential assistance through the project and drafted the distribution maps, and David Mackay, who prepared most of the illustrations (Bob Roden prepared the illustration of E. creta). Ian Brooker most helpfully drew attention to certain of the distinctive characters of the series and made suggestions for changes, which we have largely taken up.

\section{References}

Beard, J.S. (1980) A new phytogeographic map of Western Australia. Western Australian Herb. Research Notes 3: 37-58.

Bentham, G. (1867) Flora australiensis, vol. 3 (L. Reeve: London).

Blakely, W.F. (1934) A key to the eucalypts (The Worker Trustees: Sydney).

Brooker, M.I.H. \& Kleinig, D.A. (1990) A field guide to Eucalyptus, vol. 2 (Inkata: Melbourne).

Burgman, M.A. (1985) Cladistics, phenetics and biogeography of populations of Boronia inornata Turcz. (Rutaceae) and the Eucalyptus diptera Andrews (Myrtaceae) species complex in Western Australia. Austral. J. Bot. 33(4): 419-431.

Chippendale, G.M. (1988) Eucalyptus. In A.S. George (ed.), Flora of Australia, vol. 19 (AGPS: Canberra).

Hill, K.D. (1989) Mallee eucalypt communities: their classification and biogeography. Pp. 93-108, in J.C. Noble \& R.A. Bradstock (eds.), Mediterranean landscapes in Australia: Mallee ecosystems and their management (CSIRO: Melbourne).

Lang, P.J. \& Brooker, M.I.H. (1990) Two new mallee species from South Australia in Eucalyptus L'Hérit. series Rufispermae Maiden. J. Adelaide Bot. Gard. 13: 65-78 (1990).

Maiden, J.H. (1903-1933) A critical revision of the genus Eucalyptus (Govt. Printer: Sydney). Pryor, L.D. \& Johnson, L.A.S. (1971) A classification of the eucalypts (ANU Press: Canberra).

Manuscript received 15 June 1990

Manuscript accepted 15 November 1990 